\title{
WASTEWATER TREATMENT FOR HEAVY METALS AND DYES USING LOW-COST BIOSORBENTS: A REVIEW
}

\author{
Andreea BONDAREV \\ Petroleum-Gas University of Ploiesti, Romania \\ e-mail: andreeabondarev@yahoo.com
}

\begin{abstract}
The pollution of industrial wastewater with heavy metals and dyes is a highly important environmental problem, because of the propagation of the pollution and because of its unfavourable consequences. Sustainable wastewater treatment is one of the foremost challenges of this century. Various waste materials characterized by lignocellulose composition are low cost, non-conventional adsorbent for biosorptive removal of heavy metal ions from aqueous solutions. Recent studies point to the potential of use of low-cost materials (zeolites, carrot residue and green tea waste) as effective sorbents for the removal of $\mathrm{Cd}^{2+}$ from aqueous solution. The use of bentonite to the treatment of wastewater containing reactive dyes in aqueous solutions requires the modification of the hydrophilic surface by inorganic cations with organic cations exchange. The use of bentonite as an inexpensive sorbent for the removal of Remazol Brilliant Blue $R(R B B R)$ from synthetic aqueous solutions has been also presented in recent studies. The influence of some parameters such as: $\mathrm{pH}$, initial dye concentration, sorbent dose on sorption kinetics for dye removal has been reviewed in this paper.
\end{abstract}

KEYWORDS: adsorption, heavy metals, dyes, waste materials, removal

\section{Introduction}

Wastewater treatment for organic and inorganic pollutants is one of the foremost areas of scientific research involving many fields of science and engineering. According to WHO and UNICEF, 2000 report approximately $70-80 \%$ of total illnesses in developing countries are caused by different water contaminants. With the increasing levels of industrial toxic sludge disposal to water bodies, finding environment friendly and affordable treatment methods is a priority. Adsorption is one of the most researched and used wastewater treatment methods for removing heavy metals and dyes. The need for alternative treatment techniques with wide scale applicability led to a new area: the green chemistry or green technology, which dealt with technological interventions for environmental sustainability by focussing on minimizing pollution and use of nonrenewable resources [1].

Various waste materials characterized by lignocellulose composition are low cost, nonconventional adsorbent for biosorptive removal of heavy metal ions from aqueous solutions. The sorption of synthetic dyes on solid materials based on wood wastes have been intensively studied. For example, wood sawdust is a promising natural lowcost material for the treatment of polluted wastewater $[1,2]$.

Efficient removal of heavy metal ions from wastewater has become an important issue in many countries. Conventional methods have been widely used to remove heavy metals from water: chemical precipitation, chemical oxidation, chemical reduction, ion exchange, filtration, electrochemical treatment and evaporation. All of these procedures have some disadvantages, such as high energy requirements, incomplete disposal and the production of toxic sludge or waste that also requires additional treatment [2-8].

Adsorption is an effective method for removing trace pollutants from water. Activated carbon is widely used as an adsorbent support of different metal ions. Activated carbon requires complexing agents to improve its removal performance for inorganic contaminants. These procedures have an important disadvantage: the high cost of the activation process limits the use of activated carbon sorbent in wastewater treatment $[4,8]$.

Different types of functionalized materials have been developed for the removal of heavy metals ions 
from wastewater: mesoporous and microporous silica, clays or organic polymers $[5,6]$. Clinoptilolite occurring in the zeolitic volcanic tuffs is a hydrated alumina-silicate member of the heulandite group. It is widespread in our country and in the whole world. Clinoptilolite incorporation in different biopolymers membranes is an effective method to control the diffusion outside the zeolite crystals and designed composite systems have many opportunities for applications in wastewater treatment [6].

A low-cost adsorbent is defined as a material that is abundant in nature or is a by-product or residual material from an industry domain. Biomass waste, industrial waste and mineral waste have been researched in many studies and biomass has presented better adsorption capacity [2, 7-10]. Plants possess a special cellular mechanism that may be involved in the removal of heavy metals. These include the capacity for metal binding to cell walls and extracellular exudates for chelation of metals by peptides, such as phytochelatins and by metalothioneins [3].

Adsorbents of agricultural origin have polymeric groups like cellulose, hemi-cellulose, pectin, lignin and proteins as active centers for metal uptake. Various waste materials: almond shell residues, date stones, coffee ground, black tea leaves, olive leaves, carrot residue are low cost and non-conventional adsorbent for biosorptive removal of heavy metal ions from aqueous solutions [5, 11-14].

The adsorption of heavy metal ions is as a result of physico-chemical interaction, ion exchange or complex formation between metal ions and functional groups which are present on the cell surface [2]. Different functional groups are involved, such as carboxyl, amine and amides. The ion exchange mechanism takes into account the metal binding pattern and the proton release reaction [2, 15-19]. The absorption of metals and the efficiency of biosorption by the residual biomass depend on the physical and surface properties of the adsorbent, the properties of metal ions and the operating conditions [9-12, 20, 21].

Adsorption is an efficient method for removing reactive dyes. One of this method advantages is the possibility to use a wide variety of synthetic and natural materials at a reduced price [3]. In recent decades, general attention has been paid to unconventional and low-cost materials that include agricultural and industrial by-products and waste [13]. Studies in the literature have reported that biosorption could reduce by $20-36 \%$ of capital, operating and total cost compared to conventional systems [4-10].

The detection of reactive dyes in the environment can cause serious problems due to their possible toxicity, due to their aromatic structures. These compounds are stable, not biodegradable and they are difficult to remove from industrial effluents before discharging them into emissaries [1]. Different technologies have been developed for the removal of dyes from wastewater: chemical precipitation, adsorption, membrane filtration, coagulation, ion exchange, oxidation process, reverse osmosis, solvent extraction [1-3]. Physical and chemical characteristics of biosorbents are very important to understand potential application of these materials and adsorption mechanism [13, 14]. For example, wooden materials, coconut shell, pineapple leaves, sugar cane bagasse, coffee waste have the highest cellulose contents (>40\%) [16-20].

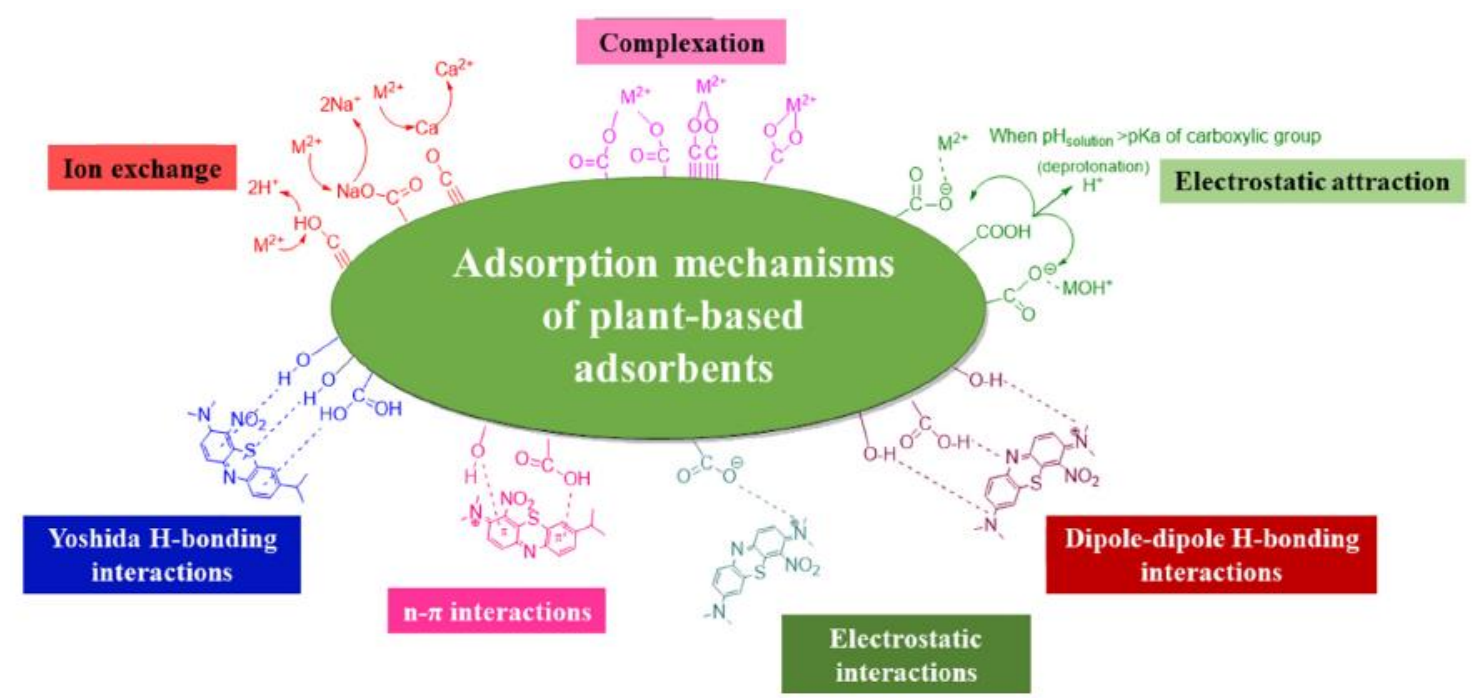

Fig. 1. Adsorption mechanism of heavy metals and dyes using plant-based adsorbents [7] 
Researchers have tried to remove heavy metals by using biosorbents; for example, the adsorption process of $\mathrm{Cd}^{2+}$ on some adsorbents was studied: clinoptillolite tuff, carrot residue and green tea waste. Carrot residues and tea waste were investigated as unconventional low-cost adsorbent materials for the absorption of $\mathrm{Cd}^{2+}$ from contaminated water under different experimental conditions: $\mathrm{pH}$, amount of adsorbent and initial concentration of metal. Equilibrium data were examined using the Langmuir, Freundlich and Temkin isotherm models [21, 22].

Use of bentonite to the treatment of wastewater containing anionic dyes, particularly reactive dyes in aqueous solutions, requires the modification of the hydrophilic surface by inorganic cations with organic cations exchange. The use of bentonite as an inexpensive sorbent for the removal of Remazol Brilliant Blue R (RBBR) from synthetic aqueous solutions has been studied in batch conditions. The influence of some parameters such as: $\mathrm{pH}$, initial dye concentration, sorbent dose on sorption kinetics for dye removal were investigated [21, 22].

\section{Biosorptive removal of heavy metals and dyes}

\subsection{Preparation of the adsorbent supports}

Recent research studies presented that clinoptillolite (CLP) and some waste materials: carrot residues (CR) and green tea waste (TW) were used as adsorbents for the removal of cadmium from synthetic wastewater.

Zeolites are crystalline microporous aluminosilicates with ion exchange properties, suitable for a wide range of applications: in catalysis, separation of liquid and gaseous mixtures and in wastewater treatment $[6,22,23]$. The natural CLP sample has the following ideal composition: $\left[\mathrm{Ca}_{1.24} \mathrm{Na}_{1.84} \mathrm{~K}_{1.76} \mathrm{Mg}_{0.2} \mathrm{Al}_{16} \mathrm{Si}_{30} \mathrm{O}_{72}\left(\mathrm{H}_{2} \mathrm{O}\right)_{21.32}\right]$. Only a selected fraction of clinoptilolite (for example 0.05 $\mathrm{mm}$ ) was used for the adsorption studies [6].

The cation exchange and/or adsorptive properties of tea and carrot residue can be attributed to the presence of carboxylic, phenolic and other functional groups, which exist in caffein either the cellulosic matrix or in the materials associated with cellulose such as hemicellulose, lignin, peptides [3, 8].

To study the morphology of the clinoptillolite surface, its structure was observed using scanning electron microscopy (SEM). Figure 2 shows SEM image of a clinoptillolite sample and indicates that it has a large distribution of particle size. The presence of nanoparticles and submicron size particles can also be observed from Figure 2 .

The carrot residues were dried at $80{ }^{\circ} \mathrm{C}$ for 24 hours, grounded to powder and sieved to obtain a homogeneous particle size adsorbent material. To remove soluble components such as tannin or coloring matters, the carrot residue was washed with $0.5 \mathrm{M} \mathrm{HCl}$ and deionized distilled water until a constant $\mathrm{pH}$ value.

Surface impurities, soluble and coloured ingredients of green tea waste were removed by washing with boiling distilled water. This action was repeated until the solution was colourless. The tea residues were then washed with distilled water and dried in the oven for 12 hours at $105{ }^{\circ} \mathrm{C}$. The dried tea residues were ground and sieved and the fine powder was then used for sorption studies [22].

Data regarding the chemical composition and the content of montmorillonite corresponding to sodium bentonite used in the laboratory experiments for some dyes removals were obtained from the supplier. The ion exchange capacity evaluated from these data was $0.75 \mathrm{~g}$ mechiv / $100 \mathrm{~g}$. The laboratory experiments were performed with a grain size fraction of sodium bentonite, with particle sizes less than 200 $\mu \mathrm{m}$, as it was obtained from the supplier [23].

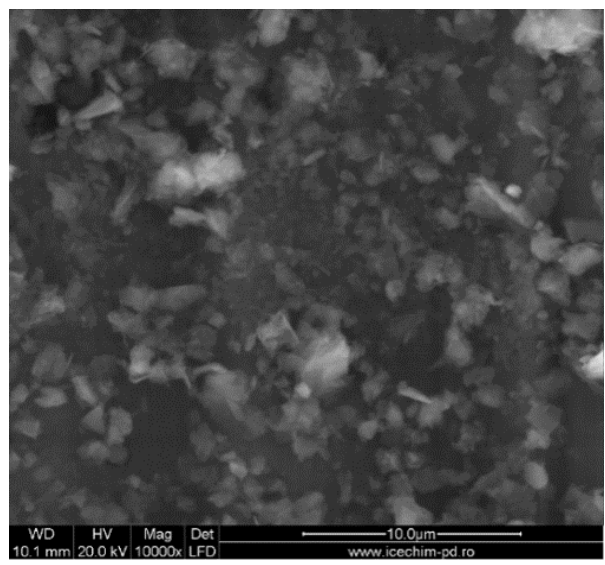

Fig. 2. SEM micrograph of clinoptillolite (CPL) [22] 


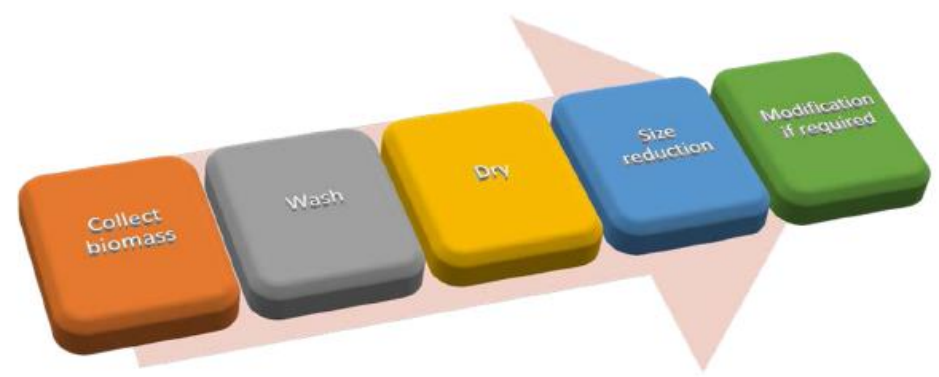

Fig. 3. General protocol for biosorbent preparation [8]

\subsection{Sorption equilibrium}

Analysis of sorption equilibrium data through isotherm models is of paramount importance for designing a biosorption system. Adsorption equilibrium data are important to optimize the parameters which characterize an adsorption system. These data are also useful to provide physicochemical information to explain the mechanism of adsorption. The absorption capacity of an adsorbent can also be described by the equilibrium sorption isotherm, which is characterized by specific constants, whose values express the surface properties and affinity of an adsorbent [12].

The adsorption capacity $\mathrm{q}_{\mathrm{e}}(\mathrm{mg} / \mathrm{g})$ after equilibrium was calculated by mass balance relationship equation as follows [4]:

$$
q_{e}=\left(C_{0}-C_{e}\right) V / W
$$

In the relationship equation (1): $C_{0}(\mathrm{mg} / \mathrm{L})$ is the initial concentration of solute, $C_{e}(\mathrm{mg} / \mathrm{L})$ is the equilibrium metal ion concentration, $\mathrm{V}$ is the volume of the aqueous solution (L) and W is the mass of the sorbent used $(\mathrm{g})$.

The percent removal of heavy metal from solution (R\%) was calculated by the following equation [4]:

$$
\% R=\left(C_{0}-C_{e}\right) / C_{0} \cdot 100
$$

where $C_{0}(\mathrm{mg} / \mathrm{L})$ is the initial concentration of metal ion, $C_{e}(\mathrm{mg} / \mathrm{L})$ is the equilibrium metal ion concentration.

The equilibrium between the liquid phase and the solid phase (adsorbent-attached solute) was described in this study by Freundlich, Langmuir and Temkin mathematical models [4, 12].

Freundlich isotherm model can be applied for non-ideal adsorption on heterogeneous surfaces or for multilayer sorption and it is represented by the following equations (Freundlich, 1906) [12-14]:

$$
q_{e}=K_{F} \cdot C_{e}{ }^{1 / n} \quad \text { (2) original form }
$$

$\lg q_{e}=\lg K_{F}+1 / n \lg C_{e} \quad$ (3) linear equation form where: $K_{F}\left(\mathrm{mg} \mathrm{g}^{-1}\right)$ and $n$ are Freundlich constants; $1 / n$ represents an empirical parameter, which is related to the adsorption intensity; $q_{e}\left(\mathrm{mg} \mathrm{g}^{-1}\right)$ is the equilibrium sorption concentration of pollutant per gram of adsorbent; $C_{e}\left(\mathrm{mg} \mathrm{L}^{-1}\right)$ represents the concentration of the solute in solution at equilibrium.

Langmuir isotherm model assumes that the adsorption process occurs at specific homogeneous sites on the adsorbent and it is described by the following equations (Langmuir, 1918) [12, 14].

$$
\begin{array}{r}
q_{e}=q_{m} \cdot K_{L} \cdot C_{e} / 1+K_{L} \cdot C \text { (4) original form } \\
\mathrm{c} / q_{e}=1 / K_{L} \cdot q_{m}+\mathrm{c} / q_{m}(5) \text { linear equation form }
\end{array}
$$

where: $q_{e}\left(\mathrm{mg} \mathrm{g}^{-1}\right)$ represents the amount of solute adsorbed per amount of adsorbent; $C_{e}\left(\mathrm{mg} \mathrm{L}^{-1}\right.$ or $\mathrm{mmol} \mathrm{L} \mathrm{L}^{-1}$ ) is the pollutant equilibrium concentration; qm $\left(\mathrm{mg} \mathrm{g}^{-1}\right)$ represents the sorption capacity; $K_{L}$ $(\mathrm{L} / \mathrm{mg})$ is the Langmuir constant related to the adsorption energy $\left(\mathrm{L} \mathrm{mg}^{-1}\right.$ or $\left.\mathrm{L} \mathrm{mmol}^{-1}\right)$.

Temkin isotherm model is represented by the following equation [14]:

$$
q=\mathrm{R} \cdot \mathrm{T} / \mathrm{b}_{\mathrm{T}} \cdot \ln \left(K_{\mathrm{T}} \cdot \mathrm{C}_{\mathrm{e}}\right) \text { (6) original form }
$$

$\mathrm{q}=\mathrm{R} \cdot \mathrm{T} / \mathrm{b}_{\mathrm{T}} \cdot \ln K_{\mathrm{T}}+\mathrm{R} \cdot \mathrm{T} / \mathrm{b}_{\mathrm{T}} \ln \mathrm{C}_{\mathrm{e}}(7)$ linear equation form

where: $K_{T}\left(\mathrm{~L} \mathrm{mg}^{-1}\right)$ and $b_{T}(\mathrm{KJ} / \mathrm{mole})$ represent Temkin isotherm constants; $C_{e}\left(\mathrm{mg} \mathrm{L}^{-1}\right.$ or $\left.\mathrm{mmol} \mathrm{L}{ }^{-1}\right)$ is the pollutant equilibrium concentration.

\subsection{Effect of water properties on adsorption of heavy metals and dyes}

\subsubsection{The adsorption of $\mathrm{Cd}^{2+}$. Effect of initial concentration}

The initial concentration is one of the parameters that have an important effect on the 
removal of adsorbate species from an aqueous solution. (Figure 4).

The effect of the initial concentration of $\mathrm{Cd}^{2+}$ on the adsorption rate was investigated for the values of
20, 40, 60 and $80 \mathrm{mg} / \mathrm{L}$. All experiments were performed at room temperature i.e., $22 \pm 2{ }^{\circ} \mathrm{C}$; the amount of adsorbent support was $0.5 \mathrm{~g}$ and contact time $24 \mathrm{~h}$ [22]
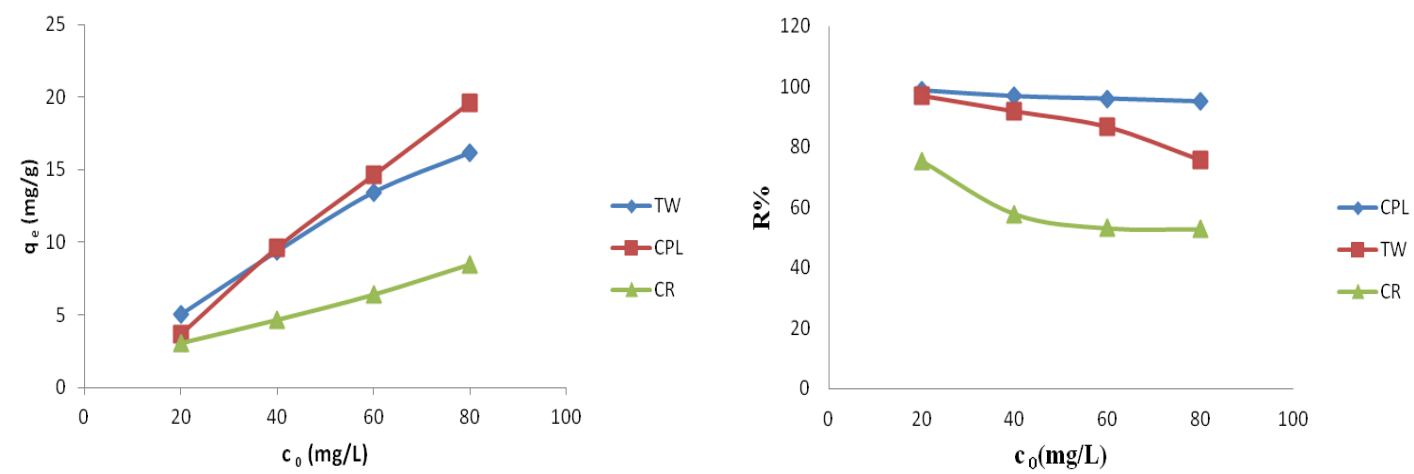

Fig. 4. Effect of initial concentration of $\mathrm{Cd}^{2+}$ on the adsorbent materials (clinoptillolite tuff CPL, carrot residue CR and green tea waste TW) [22]

The mechanism of metal absorption is especially dependent on the initial concentration of heavy metals: at low concentrations, the metal ions are adsorbed by specific sites; increasing concentration values, specific sites will be saturated and exchange sites will be filled [4].

As the initial cadmium concentrations increase, the percentage of metal removal $(\mathrm{R} \%)$ decreases. Figure 3 also indicates that CPL and TW had a better percentage elimination than CR.

\subsubsection{The adsorption of $\mathrm{Cd}^{2+}$. Effect of adsorbent mass}

The amount of adsorbent is also an important parameter in determining the adsorption capacity. As the adsorbent dosage increases, the adsorbent sites available for metal ions are also increased and therefore better adsorption process takes place [1316].

In the adsorption studies which are presented, the adsorbent mass varied from 0.10 to $1.00 \mathrm{~g}$ in 100 $\mathrm{mL}$ and $60 \mathrm{mg} / \mathrm{L} \mathrm{Cd}^{+2}$ solutions, while all the other variables were kept constant.

It was noted that the percentage of $\mathrm{Cd}^{2+}$ removal increases according the amount of sorbent mass (Figure 4), the dosage increase of CPL from 0.10 to $1.00 \mathrm{~g}$ enhances $\mathrm{Cd}^{+2}$ uptake from $69.9 \%$ to $100 \%$; in case of TW, the percent of metal removal increased from $42.9 \%$ to $92.79 \%$ and for CR from $66.1 \%$ to $80.45 \%$, in the same adsorbent amount interval. The best percentage removal of $\mathrm{Cd}^{+2}$ was at about $100 \%$, using CPL as adsorbent and an adsorbent dosage of 0.75 and $1.00 \mathrm{~g}$, in a solution of concentration 60 $\mathrm{mg} / \mathrm{L} \mathrm{Cd}^{+2}$.

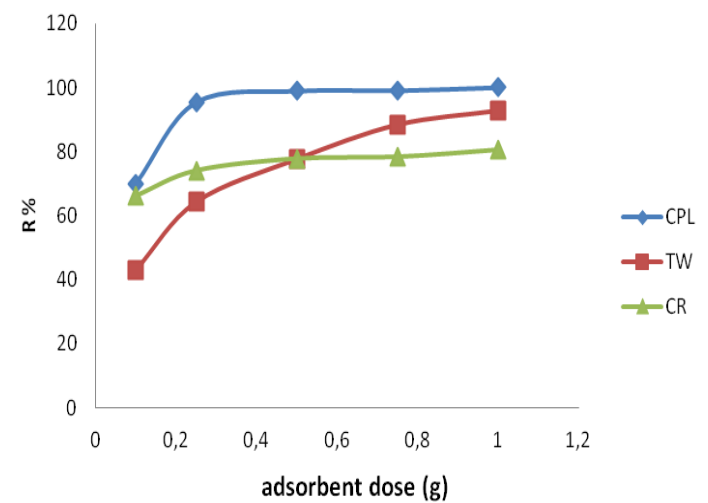

Fig. 5. Effect of adsorbent mass on the adsorption of $\mathrm{Cd}^{2+}$ using different biosorbent materials (clinoptillolite tuff CPL, carrot residue CR and green tea waste TW) [22] 


\subsubsection{The adsorption of $\mathrm{Cd} 2+$. Effect of $\mathrm{pH}$}

Solution $\mathrm{pH}$ has been reported to be one of the most important variables governing the adsorption of metal ions by an adsorbent. The equilibrium established in solution between metal ions and the sorbent may be described by the following equilibrium [15]:

$$
\mathrm{M}^{n+}+\mathrm{BH}_{n} \rightleftharpoons \mathrm{BM}+n \mathrm{H}^{+}
$$

$M$ represents the metal; $n$ is the metal charge and $B$ is the active sorption sites of the adsorbent [15].

According to equation (8), $\mathrm{pH}$ influences metal ion adsorption, due to a competition between the metal ion and $\mathrm{H}^{+}$ions for active sorption sites. $\mathrm{pH}$ affects the solubility of metal ions and the ionization states of functional groups of the adsorbent material, such as carboxyl and hydroxyl $[14,15]$.

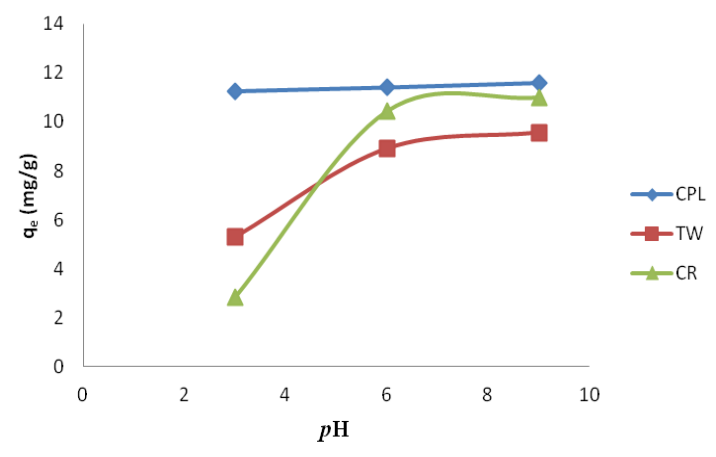

Equilibrium adsorption experiments at different $\mathrm{pH}$ values (3, 6 and 9) were performed to study the effect of $\mathrm{pH}$ on $\mathrm{Cd}^{+2}$ removal from wastewater. All other variables such as dosage, contact time and temperature were kept constant. The results are illustrated in Figure 5. As it can be observed, $\mathrm{Cd}^{2+}$ removal increases with increasing the initial $\mathrm{pH}$ of the solution. At lower $\mathrm{pH}$, the concentration of $\mathrm{H}^{+}$ion is high, causing a competition for vacant adsorbent site between the $\mathrm{H}+$ ion and heavy metal cations.

From the experiments it was observed that the optimum $\mathrm{pH}$ value for the removal of $\mathrm{Cd}^{+2}$ was 6 , using CPL, TW and $\mathrm{CR}$ as adsorbent materials. (Figure 6) The best adsorption results at $\mathrm{pH}$ value 6 could be explained because of the cellulose component of the $\mathrm{CR}$ adsorbent support, where site binding adsorption might be occurring. From the point of view of an industrial application, this may provide an important advantage, since working at extreme $\mathrm{pH}$ would be avoided.

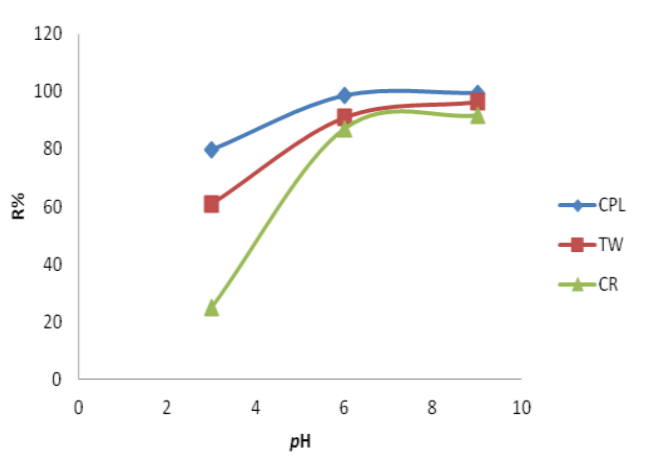

Fig. 6. Effect of $\mathrm{pH}$ on the adsorption of $\mathrm{Cd} 2+$ using different materials (clinoptillolite tuff CPL, carrot residue CR and green tea waste TW) [22]

\subsubsection{Adsorption isotherm models for $\mathrm{Cd}^{2+}$}

Equilibrium adsorption data are used to determine the maximum capacities of the adsorbents during the experiments of biosorption. The linearized Langmuir, Freundlich and Temkin isotherms of $\mathrm{Cd}^{2+}$ are shown in Figures 7-9. The adsorption intensities and adsorption capacities $\left(q_{m}\right)$ were determined from the intercept and slope data, respectively, for each adsorbent.

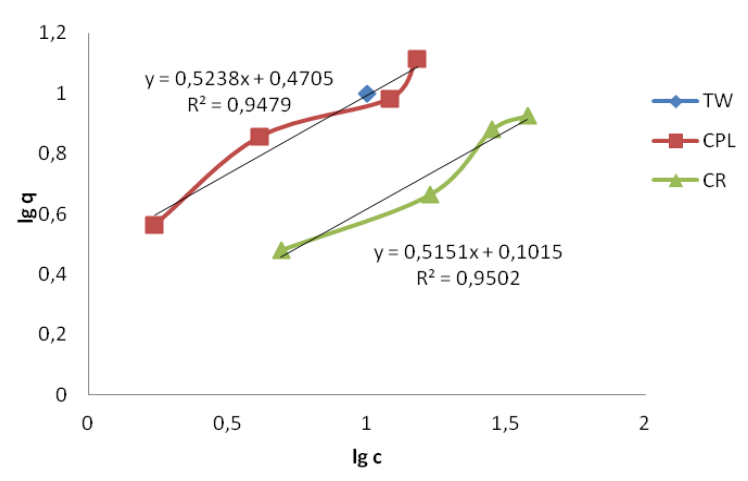

Fig. 7. Freundlich isotherm of $C d^{2+}$ removal by different types of adsorbents (clinoptillolite tuff CPL, carrot residue CR and green tea waste TW) [22] 


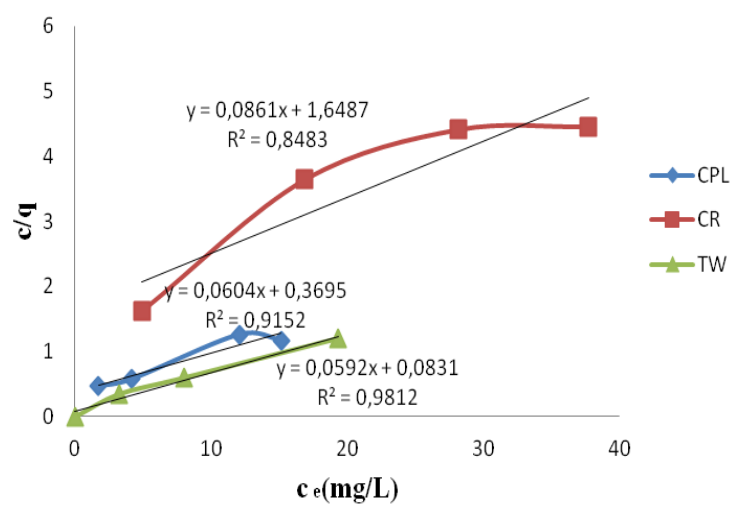

Fig. 8. Langmuir isotherm of $\mathrm{Cd}^{2+}$ removal by different types of adsorbents (clinoptillolite tuff CPL, carrot residue CR and green tea waste TW) [22]

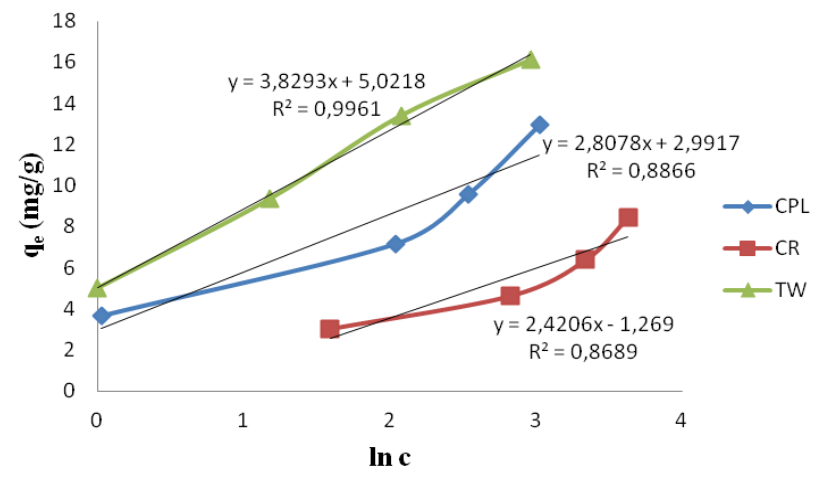

Fig. 9. Temkin isotherm of $\mathrm{Cd}^{2+}$ removal by different types of adsorbents (clinoptillolite tuff CPL, carrot residue CR and green tea waste TW) [22]

Table 1. Equilibrium adsorption data for $\mathrm{Cd}^{2+}$ sorption on some bio adsorbents [22-24]

\begin{tabular}{|c|c|c|c|}
\hline Sorbent & Langmuir Model & Freundlich Model & Temkin Model \\
\hline $\begin{array}{l}\text { Clinoptillolite } \\
\text { CPL }\end{array}$ & $\begin{array}{l}\mathrm{R}^{2}=0.9152 \\
\mathrm{q}_{\mathrm{m}}=16.55 \mathrm{mg} / \mathrm{g} \\
\mathrm{K}_{\mathrm{L}}=0.1635 \mathrm{~L} / \mathrm{mg} \\
\Delta \mathrm{G}=4.514 \mathrm{KJ} / \mathrm{Kmol}\end{array}$ & $\begin{array}{l}\mathrm{R}^{2}=0.9479 \\
\mathrm{~K}_{\mathrm{F}}=2.95 \mathrm{mg} / \mathrm{g} \\
\mathrm{n}=2.125\end{array}$ & $\begin{array}{l}\mathrm{R}^{2}=0.8866 \\
\mathrm{~K}_{\mathrm{T}}=3.539 \mathrm{~L} / \mathrm{g} \\
\mathrm{b}_{\mathrm{T}}=0.8281 \mathrm{KJ} / \mathrm{mol}\end{array}$ \\
\hline $\begin{array}{l}\text { Carrot residue } \\
\text { CR }\end{array}$ & $\begin{array}{l}\mathrm{R}^{2}=0.8483 \\
\mathrm{q}_{\mathrm{m}}=11.614 \mathrm{mg} / \mathrm{g} \\
\mathrm{K}_{\mathrm{L}}=0.0522 \mathrm{~L} / \mathrm{mg} \\
\Delta \mathrm{G}=7.357 \mathrm{KJ} / \mathrm{Kmol}\end{array}$ & $\begin{array}{l}\mathrm{R}^{2}=0.9502 \\
\mathrm{~K}_{\mathrm{F}}=1.26 \mathrm{mg} / \mathrm{g} \\
\mathrm{n}=1.94\end{array}$ & $\begin{array}{l}\mathrm{R}^{2}=0.8689 \\
\mathrm{~K}_{\mathrm{T}}=1.688 \mathrm{~L} / \mathrm{g} \\
\mathrm{b}_{\mathrm{T}}=1.006 \mathrm{KJ} / \mathrm{mol}\end{array}$ \\
\hline $\begin{array}{l}\text { Tea waste } \\
\text { TW }\end{array}$ & $\begin{array}{l}\mathrm{R}^{2}=0.9812 \\
\mathrm{q}_{\mathrm{m}}=16.89 \mathrm{mg} / \mathrm{g} \\
\mathrm{K}_{\mathrm{L}}=0.7124 \mathrm{~L} / \mathrm{mg} \\
\Delta \mathrm{G}=0.848 \mathrm{KJ} / \mathrm{Kmol}\end{array}$ & $\begin{array}{l}\mathrm{R}^{2}=0.9673 \\
\mathrm{~K}_{\mathrm{F}}=6.70 \mathrm{mg} / \mathrm{g} \\
\mathrm{n}=3.26\end{array}$ & $\begin{array}{l}\mathrm{R}^{2}=0.9961 \\
\mathrm{~K}_{\mathrm{T}}=1.57 \mathrm{~L} / \mathrm{g} \\
\mathrm{b}_{\mathrm{T}}=0.6470 \mathrm{KJ} / \mathrm{mol}\end{array}$ \\
\hline $\begin{array}{l}\mathrm{NaOH} \text {-modified } \\
\text { lemon peel }\end{array}$ & $\begin{array}{l}\mathrm{R}^{2}=0.984 \\
\mathrm{q}_{\mathrm{m}}=80.64 \mathrm{mg} / \mathrm{g} \\
\mathrm{K}_{\mathrm{L}}=0.9910 \mathrm{~L} / \mathrm{mg} \\
\Delta \mathrm{G}=0.8 \mathrm{KJ} / \mathrm{Kmol}\end{array}$ & $\begin{array}{l}\mathrm{R}^{2}=0.917 \\
\mathrm{~K}_{\mathrm{F}}=5.58 \mathrm{mg} / \mathrm{g} \\
\mathrm{n}=6.9\end{array}$ & $\begin{array}{l}\mathrm{R}^{2}=0.8849 \\
\mathrm{~K}_{\mathrm{T}}=5.576 \mathrm{~L} / \mathrm{g} \\
\mathrm{b}_{\mathrm{T}}=0.3426 \mathrm{KJ} / \mathrm{mol}\end{array}$ \\
\hline
\end{tabular}

The results presented in table 1 shows that CPL, $\mathrm{NaOH}$-modified lemon peel and TW exhibited greater adsorption capacities than the values registered for $\mathrm{CR}$ adsorbent. It can be observed from the data presented in the Table 1 that the value of ' $n$ '
Freundlich specific parameter was greater than 1, which indicates that the adsorption process of $\mathrm{Cd}(\mathrm{II})$ on all biosorbents which were tested (CPL, CR and TW) was favourable. 
According to literature studies, the Temkin isotherm considers that the heat of adsorption of molecules would decrease linearly with the coating due to the adsorbed species / adsorbent support interactions [20, 21]. The Temkin $\mathrm{b}_{\mathrm{T}}$ (KJ / mol) specific parameter related to the sorption heat is less than 8 for all adsorbents which were tested, indicating a weak interaction between metal and sorbent. [22] The process, as indicated by the Temkin $b_{\mathrm{T}}$ parameter, can be expressed as physiosorption [2224, 29].

\subsubsection{The adsorption of Remazol Brilliant} Blue $\mathrm{R}$ dye (RBBR). The influence of initial $\mathrm{pH}$

The presence of coloured organic compounds in water causes the decrease in penetration of sun light, that may affect the photosynthetic activity of aquatic plants. Various components of dyes like aromatics, amines are mainly responsible for their toxicity [8].

The use of bentonite as an inexpensive sorbent for the removal of Remazol Brilliant Blue R (RBBR) from synthetic aqueous solutions has been also presented in recent studies. The use of sodium bentonite to the treatment of wastewater containing reactive dyes requires the modification of the hydrophilic surface by inorganic cations with organic cations exchange. The modification of sodium bentonite with organic cations was achieved by ion exchange, according to procedures reported in the literature [23].

The influence of initial $\mathrm{pH}$ in the domain 8-11 and the influence of the initial concentration of the reactive dye (concentration domain $C_{0}: 50-100 \mathrm{mg} / \mathrm{L}$ ) were presented in a research study for the adsorption process of Remazol Brilliant Blue R dye [23].

Figure 10 presents the results of the adsorption tests of RBBR dye at different values of $\mathrm{pH}$. The initial concentration of dye in solution was: $C_{0}=50$ $\mathrm{mg} / \mathrm{L}$ and the adsorbent concentration of $10 \mathrm{~g} / \mathrm{L}$ [23].

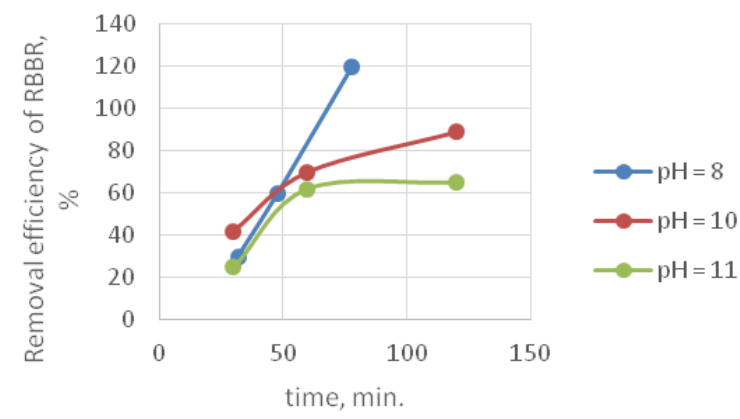

Fig. 10. The results of the adsorption tests of Remazol Brilliant Blue $R$ (RBBR) dye at different values of $p H[23]$
Figure 10 shows that $\mathrm{pH}$ of the dye solution is an important factor in the process of adsorption of Remazol Brilliant Blue R (RBBR) anthraquinone dye. In the first part of the process small differences occur in the domain which was studied, but significant differences between the samples can be observed as the contact time increases.

It is obvious that the maximum efficiency was obtained in case of RBBR dye adsorption at $\mathrm{pH}=10$ (a removal efficiency of $89 \%$, for a contact time of $120 \mathrm{~min}$ ). This result was taken into consideration for the following experiments of the dye adsorption [23].

\subsubsection{The adsorption of Remazol Brilliant} Blue R dye (RBBR). The influence of initial concentration of dye solution

Figure 11 presents the data obtained in recent research experiments in which the influence of the initial concentration of dye solution Remazol Brilliant Blue R was studied (for initial dye concentrations of 50 and $100 \mathrm{mg} / \mathrm{L}$ at $\mathrm{pH} 10$ and the temperature of 25 $\left.{ }^{\circ} \mathrm{C}\right)$, on the bentonite sample NaB-S1 (CTAB $=1.3$ CEC) [23].

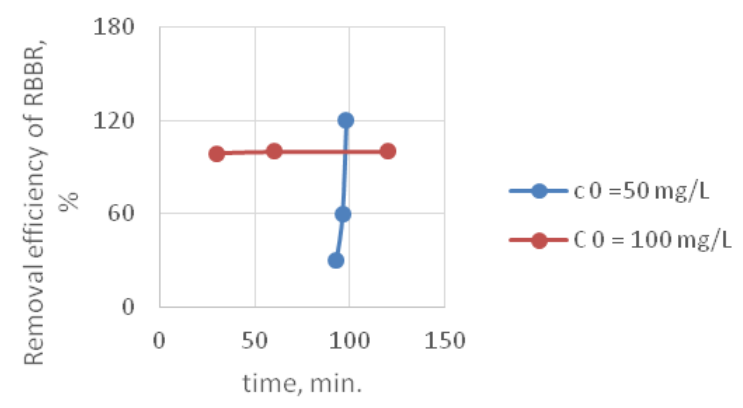

Fig. 11. The data obtained in experiments with the initial concentration of dye solution Remazol Brilliant Blue R RBBR $\left(C_{0}=50\right.$ and $\left.100 \mathrm{mg} / \mathrm{L}\right)$ at $\mathrm{pH}=10$ and the temperature of $25^{\circ} \mathrm{C}$, on the bentonite sample NaB-S1 [23]

It can be observed that at a concentration of 100 $\mathrm{mg} / \mathrm{L}$, the adsorption process is very fast, so that the total removal of the dye takes place in a contact time of $30 \mathrm{~min}$. The comparison of the two sets of samples shows that in case of lower initial concentration (50 $\mathrm{mg} / \mathrm{L}$ ) kinetics of the process is slower, but adsorption efficiency in the first $30 \mathrm{~min}$. of contact is over $90 \%$ [23].

In the past few years, an enormous amount of research has been conducted on biosorbents. Uptake capacities of various bio adsorbents for dyes removal are presented in Table 2 . 
Table 2. Uptake capacities of various bio adsorbents for dyes removal

\begin{tabular}{|c|c|c|c|}
\hline Adsorbent & Organic pollutant - dye & Amount adsorbed & References \\
\hline Orange peel waste & Toluidine blue & $314.3 \mathrm{mg} / \mathrm{g}$ & {$[24]$} \\
\hline Bentonite & Remazol Brilliant Blue R & $198.3 \mathrm{mg} / \mathrm{g}$ & {$[23]$} \\
\hline Grapefruit peel & Crystal violet & $254.16 \mathrm{mg} / \mathrm{g}$ & {$[25]$} \\
\hline $\begin{array}{c}\text { Cucumis sativa fruit } \\
\text { peel }\end{array}$ & Malachite green & $36.23 \mathrm{mg} / \mathrm{g}$ & {$[26]$} \\
\hline Pomelo peel & Methylene blue & $133 \mathrm{mg} / \mathrm{g}$ & {$[27]$} \\
\hline $\begin{array}{c}\text { Activated carbon from } \\
\text { pomelo peels }\end{array}$ & Malachite green & $178.43 \mathrm{mg} / \mathrm{g}$ & {$[28]$} \\
\hline $\begin{array}{c}\text { Coffee wastes carbon } \\
\text { and red mud } \\
\text { composite }\end{array}$ & Reactive red & $139.5 \mathrm{mg} / \mathrm{g}$ & {$[29]$} \\
\hline $\begin{array}{c}\text { Sodium alginate and } \\
\text { wastes of oil extraction } \\
\text { from almond peanut } \\
\text { composite }\end{array}$ & Methyl blue & $222.8 \mathrm{mg} / \mathrm{g}$ & {$[30]$} \\
\hline
\end{tabular}

\section{Conclusions}

The pollution of industrial wastewater with heavy metals and dyes is a highly important environmental problem, because of the propagation of the pollution and because of its unfavourable consequences. Sustainable wastewater treatment is one of the foremost challenges of this century.

In the past few years, an enormous amount of research has been conducted on biosorbents. The current review focused on the preparation and applications of waste biomass and zeolite adsorbents for the sequestration of heavy metals and dyes.

Biosorbents, agricultural waste materials and lignocelluloses waste biomass have been widely used for dye and heavy metal sequestration from wastewater.

Due to the low cost and good absorption capacity, the sorbents derived from waste products are promising biosorbent materials. Tea consumption is global and tea waste can be easily purchased, so it can be stated that tea waste has a high potential for applications in wastewater treatment. Carrot residues are also biodegradable and low-cost biosorbents with a good potential to remove heavy metals.

Use of bentonite to the treatment of wastewater containing reactive dyes in aqueous solutions was also presented in this study. The use of bentonite as an inexpensive sorbent for the removal of Remazol Brilliant Blue R (RBBR) from synthetic aqueous solutions was studied in batch conditions. The influence of some parameters such as: $\mathrm{pH}$, initial dye concentration, sorbent mass on sorption kinetics for dye removal were investigated. The research studies presented in this chapter show that bentonite is an effective adsorbent for the removal of Remazol Brilliant Blue R dye from aqueous solutions. There is a variety of aspects that should be taken into account for achieving maximum removal of both dyes and heavy metals. Achieving a combinatorial optimality between the biosorption parameters and removal efficiency remains a challenging task for the researchers.

The reviewed literature proved that instead of many chemicals, non-hazardous materials can be used as heavy metal and dyes removers from wastewaters and industrial effluents to overcome water pollution. The use of non-conventional, low-cost biosorbents has many benefits, including low investment cost, simplicity of operation and a remarkable performance.

\section{Appendices and Nomenclature}

Clinoptillolite (CLP)

Carrot residues (CR)

Green tea waste (TW)

Remazol Brilliant Blue R (RBBR)

\section{References}

[1]. Ata S., Hamid W., Rukh S., Hamid S., Syed A., Din I., Mohsin I., Turkish Journal of Biochemistry, 37 (3), p. 272-279, 2012.

[2]. Amarasinghe B. M., Williams R. A., Chemical Engineering Journal, 132, p. 299-309, 2007.

[3]. Eslamzadeh T., Nasernejad B., Bonakdar Pour B., Zamani A., Esmaail B. M., Iranian Journal of Science \& Technology, Transaction A, 28 (A1), p. 161-167, 2004.

[4]. El-Ashtoukhya E.-S. Z., Amina N. K., Abdelwahabb O., Desalination, 223, p. 162-173, 2008.

[5]. Wingenfelder U., Nowack B., Furrer G., Schulin R., Water Research 39, 200, p. 3287-3297.

[6]. Horsfall M., Spiff A., Acta Chim. Slov., 52, p. 174-181, 2005.

[7]. Tunali S., Cabuk A., Akar T., Chemical Engineering Journal, 115, p. 203-211, 2006. 


\section{THE ANNALS OF “DUNAREA DE JOS” UNIVERSITY OF GALATI \\ FASCICLE IX. METALLURGY AND MATERIALS SCIENCE \\ $\mathrm{N}^{\circ} .2$ - 2021, ISSN 2668-4748; e-ISSN 2668-4756 \\ Article DOI: https://doi.org/10.35219/mms.2021.2.08}

[8]. Yadav S., Yadav A., Bagotia N., Sharma A., Kumar S., Journal of Water Process Engineering, 42, 102148, 2021.

[9]. Cay S., Uyanik A. Ozajik, Sep. Purif. Technol. 38, p. 273280, 2004.

[10]. Egila J. N., Dauda B., Jimoh T., African Journal of Biotechnology, 9(48), p. 8192-8198, 2010.

[11]. Razmovski R., Ciban M., Ecological Engineering, 34, p. 179-186, 2008.

[12]. Mondal M. K., Journal of Environmental Management, 90, p. 3266-3271, 2009.

[13]. Ibrahima H., Jamila T., Hegazyb E., Journal of Hazardous Materials, 182, p. 842-847, 2010.

[14]. Ozdes D., Duran C., Senturk H., Journal of Environmental Management, 92, p. 3082-3090, 2011.

[15]. Suteu D., Zaharia C., Chemical Bulletin of "Politehnica" University of Timisoara, Romania, Series of Chemistry and Environmental Engineering, 56(70), p. 85, 2011.

[16]. Jacob J. S., Roberto L.-R., Rivera J., Ocampo R., CerinoCordova F., Sustainable Environment Research, 27, p. 32, 2017. [17]. Subramani S. E., Thinakaran N., Process Safety and Environmental Protection, 106, p. 1, 2017.

[18]. Auta M., Hameed B. H., Chem. Eng. J., 175, p. 233, 2011. [19]. Malik R., Ramteke D. S., Wate S. R., Waste Management, 27, p. $1129,2007$.

[20]. Paul S. A., Chavan S. K., Oriental Jr. Chem., 27, p. 4, 2011 [21]. Singha B., Das S. K., Colloids and Surfaces B, 107, p. 97, 2013.

[22]. Bondarev A., Pantea O., Mihai S., Calin C., Gheorghe C. G., REV.CHIM., 67 (4), p. 728-733, 2016.
[23]. Bombos D., Ganea R., Matei V., Marinescu C., Bondarev A., Mihai S., Natu T., Tamas I., REV. CHIM. (Bucharest), 65 (8), p. 976-982, 2014.

[24]. Lafi R., Rezma S., Hafiane A., Removal of toluidine blue from aqueous solution using orange peel waste (OPW), Desalin. Water Treat., p. 1-12, 2014.

[25]. Owamah H., Chukwujindu I., Asiagwu A., Biosorptive capacity of yam peels waste for the removal of dye from aqueous solutions, Civil Environ. Res., 3, p. 36-47, 2013.

[26]. Santhi T., Manonmani S., Malachite green removal from aqueous solution by the peel of Cucumis sativa fruit, Clean Soil Air Water, 39, p. 162-170, 2011.

[27]. Hou S., Adsorption properties of pomelo peels against methylene blue in dye wastewater, Adv. Mater. Res., 634-638, p. 178-181, 2013.

[28]. Bello O. S., Ahmad M. A., Semire B., Scavenging malachite green dye from aqueous solutions using pomelo (Citrus grandis) peels: kinetic, equilibrium and thermodynamic studies, Desalin. Water Treat., p. 1-15, 2014

[29]. Bello K., Sarojini B. K., Narayana B., Rao A., Byrappa K., A study on adsorption behavior of newly synthesized banana pseudo-stem derived superabsorbent hydrogels for cationic and anionic dye removal from effluents, Carbohydr. Polym., 181, p. 605-615, 2018.

[30]. Erfani M., Javanbakht V., Methylene Blue removal from aqueous solution by a biocomposite synthesized from sodium alginate and wastes of oil extraction from almond peanut, Int. J. Biol. Macromol., 114, p. 244-255, 2018. 